\title{
EARLY CHRISTIAN VALUES IN CULTURAL ENCOUNTER, ZEUS AND THE RAIN, MAMMON AND MODERN MEDICINE MEN
}

\author{
Cilliers Breytenbach \\ Department of New Testament, Stellenbosch University \\ Institut für Christentum und Antike \\ Humboldt-Universität Berlin
}

\begin{abstract}
The aim of the article is to revitalize traditional Christian values to prevent them from getting lost. For the Judaeo-Christian tradition, the confession to one living God is the cornerstone of the intra-cultural encounter. For Christianity the relative worth of wealth is an essential principle. Mammon is to be used in view of the future good of humanity. The task of interpreting tradition is a common theological one. In taking care of the poor and the weak, in taking responsibility for them, there is a huge demand on the wealthy and the strong. Bearing in mind that in the beginnings of Christianity the poor and the weak were entrusted to the bishop, there is a huge responsibility on church leadership. Reinterpreting Jesus' eschatological warnings, the long term dignity of humanity is the touchstone for Christian engagement within the world.
\end{abstract}

Key Words: Theology of Early Christianity; God the Creator; Christian Ethics; Poverty and Wealth in the New Testament; Hermeneutics of Eschatology

This article ${ }^{1}$ reflects on the relevance of Christian values for a general humane ethos, an ethos that leads to action that furthers and sustains the dignity of human beings. An important prerequisite for such a value is that it must be accepted by the community and that it must be functional. In order to illustrate the functioning of such a conviction I shall argue in the first part of this article that in cultural encounter early Christianity was able to contextualise its Jewish-Christian tradition in such a manner that it absorbed indigenous religious knowledge and integrated it into a manner of worship which became a cornerstone of the worldview of the local population. I treat this example under the topic Zeus and the rain.

In the second section of the article I shall argue that the more recent neglect of another central Christian value has inhumane consequences. This example will be treated under the subsection Mammon and the medicine men.

The article was first presented as a paper read at the summer school "Role and function of indigenous knowledge for ethics and religion in the context of a globalized world", organised jointly by the HumboldtUniversität zu Berlin and Stellenbosch University, Stellenbosch 26-28 February 2013. 


\section{The Supremacy of an Early Christian Value in Cultural Encounter}

\section{Zeus}

I do not wish to talk about Zeus in general. The reverence of and the devotion to a deity is always local. So I wish to invite you to travel with me to Asia Minor, to what is today Turkey, in the region of Konya. Central Anatolia is divided by various mountains, which seam the space between them, forming natural geographically independent catchment basins. The Lycaonian basins were seamed in the south by the northern side of the Taurus, all had their major cities; from west to southeast Philomelium (Akşehir), Tyriaeum (Ilgın), Laodicea Combusta (Lâdik), Iconium (Konya) and Laranda (Karaman). The basin around Iconium is fringed by mountains on the northern, western, southern and eastern borders, their protruding hills allowing a soft descent into a basin without drainage, a grassy lowland, which the Turks call an ova. The Konya-ova has in the form of a crescent the watershed running along the topographical pyramids: In the northwest and north of Konya the Boz Dağ surpasses the 2000 meters mark, in the west the peaks of the Erenler Dağ 1 tower 2290 meters and higher, separating the catchment area from eastern Pisidia. These mountains, which form the dividing line of the watershed, cause the flow to sink in the Konya-ova. The snow melting in spring in the mountains and the seasonal rain annually causes the water of the smaller rivers now blocked by the Sille, Altınapa, and May dams, and of the Çarşamba river, to fill the shallow lakes in the lower areas northeast, east and south of Konya and to flood the lowlands (Hütteroth and Höhfeld 2002:57-60, 222-224).

Ancient settlers preferred hills, terraces, moulds, and the areas around the lakes into which the water, caught in the ovas, drained. Melting snow from and the spring storms on the mountains feed the Çaramba which is the life-giving vein of the area south of Konya up to the present day. In spring the strong currents feeding lakes at the lower sections of the plain are increased by heavy rain accompanying the annual cyclones. These spring storms are just in time for the summer crops.

On the eastern side of the Çaramba the hills rising up to form the Kara Dağ (Boratinon Mountain) stop the Çaramba's eastward flow. Before the intervention of modern engineers, the strong river, unable to carry its waters to a shore, flowed into a flat arid area northeast of Çumra, splitting into channels. In antiquity, after the spring rains, it flooded the lower areas northeast of Çumra. By the end of summer the perennial river still distributed water for irrigation through its natural channels, ensuring sustainable agricultural activity.

Human settlers kept to the hills surrounding the ova, preferring the little valleys with their brooks and creeks between the hills leading up to the mountains covered in wild oak, pine trees, and junipers. The red soil and climate on the hills ensured good pasture for small stock and allowed the growing of wheat and grapes, the gradient traditional forms of irrigation. In spring even the lower lying plains are covered with green grass, shrubs and bulbous flowers, amongst them the wild tulip, but from June or July the scorching sun turns everything yellowish brown. It is easy to realize that rain is everything.

Long before the Greeks came, the Luwian population, a subsection of the Hittite kingdom, revered the god Tarchunt or Runt. He was very much the Luwian counterpart to Syrian Ba'al, a vegetation and rain god. As regards the Greeks, this god was successfully renamed Zeus (cf. Breytenbach 1996:53-75). In the region north of the Sultan Dağ, in Chihanbeyli and in Lâdik, altars from imperial times were found - dedicated to Zeus. The interesting thing about these Zeus altars is that Zeus is not carrying only his thunderbolts; over his right shoulder he has a bundle of wheat. On the side panels the bundle of wheat is repeated or there is a bunch of grapes. This Zeus is clearly the God of the weather and the 
vegetation. From Phrygian areas northwest of the current area we know that Zeus carried the epithets eukarpios (goodfruit) epikarpios (for-the-fruit). The reverence of such a deity makes perfect sense if the plowing of the fields, the sowing, and the crops depend entirely on the spring storms which caused the snow to melt and let the rivers fill up the drainage basin. The next summer comes and, if Zeus was angered, the population will starve.

In the mid-forties of the first century Barnabas and Paul visited the area where the Çarşamba flows. They were from the Roman colony of Lystra. The local Lycaonians regarded them as Gods, and we read in the Acts of the Apostles 14:11-13:

When the crowds saw what Paul had done, they shouted in the Lycaonian language, 'The gods have come down to us in human form!' Barnabas they called Zeus, and Paul they called Hermes, because he was the chief speaker. The priest of Zeus, whose temple was just outside the city, brought oxen and garlands to the gates; he and the crowds wanted to offer sacrifice. $^{2}$

Of course we understand why it was important to sacrifice to Zeus. Now, how did Luke tell the story about the reaction of the Apostles?

\section{One God for the Rain}

When the apostles Barnabas and Paul heard of it, they ripped their clothes and rushed out into the crowd, shouting, "Friends, why are you doing this? We are mortals just like you, and we bring you good news, that you should turn from these worthless things to the living God, who made the heaven and the earth and the sea and all that is in them. In past generations he allowed all the nations to follow their own ways; yet he has not left himself without a witness in doing good - giving you rains from heaven and fruitful seasons, and filling you with food and your hearts with joy." Even with these words, they scarcely restrained the crowds from offering sacrifice to them. (Acts 14:14-18)

I can be very brief here (cf. Breytenbach 1996:53-75). For the italic parts of the speech Luke imagined the disciples spoke, he takes up known motives from the traditions of first century Judaism. The notion of the living God is used in Esther, Daniel and Judith to underscore that the Lord of the Jews is the real saviour and helper, not the dead stone images of the gentiles. That the living God is the creator of heaven and earth and everything in it, resounds the Decalogue: "For in six days the LORD made heaven and earth, the sea, and all that is in them" (Exod 20:11). What is peculiar is the underlined utterance, the combination of the motif of creation with the motif of God as the giver of the fruit bearing season. This motif is also biblical ( $\operatorname{Ps}^{\mathrm{LXX}} 106: 34$; 148:9; Jer 2:21; cf. Jos. Asen. 2:11; 16:23), but the combination shows that according to Acts Paul and Barnabas did what the Greeks had done 300 years before them. The Greeks did not abandon the Hittite-Luwian Tarchunt, they superimposed Zeus on him. Now Zeus as the highest god of the pantheon became a vegetation god, too, taking over functions of Demeter or Ceres. Christianity with its monotheistic concept of one living God, who is the creator and sustainer of humankind, was able to integrate the functions of local Zeus into their devotion of God. This was very successful. Funerary inscriptions from the later 2nd, 3rd, and 4th centuries from this area give evidence of a thriving Christian community (cf. Breytenbach and Zimmermann, forthcoming) that still depended on the spring rain to guarantee their crops and the water for them and their livestock. Now they had crosses on their tombstones, but they still decorated them with images of grape bunches. They were represented at all the great ecumenical

All translations of biblical texts are taken from New Revised Standard Version (NRSV), exceptions are noted. 
councils, at Nicaea, Ephesus, Constantinople, and Chalcedon (cf. Destephen 2008). Their concept of God had advanced to that of the triune God. They believed the life-giving spring rain, the following fruitful season, and the bread came from him. He was the basis of their existence, because they perceived him to control the rain.

From Lycaonia in the 1st century we can see how a process of successful cultural encounter took place. It was not a case of supplementation, but of integration. Indigenous tradition was taken up in such a way that the function of the old deity was taken over by the new one, who became more than Zeus ever was, Creator of everything. In this sense the reverence of the one and only living God could replace more than only Zeus, also including other deities of the region. Gradually, as the Christianization of the region proceeded, the reverence for the deified Caesars was terminated and dedications to Dionysus and Pantheos, to Hermes (and Zeus?), to Gaia (Gē), and to Pluto ceased. Desecrators of graves had not to deal with Men of the heavens and of the underworld any longer, but with the wrath of the living God (cf. Breytenbach and Zimmermann, forthcoming).

Jewish Christian tradition replaced the gods of the Greeks, only later to make room for Allah after the Arab invasion of the 7th century. Today one is less dependent on the rain. Borehole after borehole covers the Lycaonian plain. If the Christians were still there, they would pray that God keeps the water table up, but now the Turkish farmers pray to Allah. In the next generation they might all watch the weather forecast on television. Then the dependence on the rain god, renamed so successfully, would shift to the satellite map and the isobars indicating atmospheric pressure. That does not mean, however, that all the other roles the revered god plays in the lives of the devotees also disappears, but the example suffices to illustrate that, depending on the cultural context, long cherished values can become obsolete, when there is no need for them anymore. So let us turn to a value that Christianity inherited from Jesus, but that has been forgotten, although there is still a need for it.

\section{The Loss of an early Christian Value in Cultural Encounter}

\section{Contra Mammon}

The word Mammon is a Canaanite loanword with the original meaning 'food, maintenance, provisions,' probably from the root $m w n$. The Aramaic māmôn meaning 'wealth, property' is used in transliteration in Luke 16:9, 11; it does not occur in Biblical Hebrew but in the Mishnah (Abot R. Nat. 2:17) and in the Damascus document (4QD ${ }^{\mathrm{d}}$ frg. 11, col. 1, 1. 4; cf. Parry and Tov 2004:138-139) and scrolls from Qumran (1QS 6:2; 1Q27 frg. 1, col. 2, 1. 5; 4Q261 3:3). It is used personified, 'Mammon' in the Sayings Gospel Q (Matt 6:24/Luke $16: 13) .^{3}$

The wisdom saying of Jesus in Matt 6:24 formulates: "No man can serve two masters: for either he will hate the one, and love the other; or else he will hold to the one, and despise the other. Ye cannot serve God and mammon" (trans. King James Version).

This saying has its wider context in Jewish wisdom tradition, where the poor has a special place. Psalm 86:1 starts, "Incline your ear, O LORD, and answer me, for I am poor and needy." Proverbs 15:15-16 formulates, "All the days of the poor are hard, but a cheerful heart has a continual feast. Better is a little with the fear of the LORD than great

$\mathrm{Q}$ is a construct, based on the agreements in Matt and Luke not found in Mark. For a hypothesis how the text taken from Q could be reconstructed and translated into English, cf. Robinson 2001. 
treasure and trouble with it." Proverbs 23:4 instructs, "Do not wear yourself out to get rich; be wise enough to desist." The relativity of wealth is stressed by Sirach 11:18-19: "Others grow rich by pinching and scraping, and here is the reward they receive for it: although they say, 'Now I can sit back and enjoy the benefit of what I have got,' they do not know how long this will last; they will have to leave their goods to others and die." Ownership ends with death, and wealth changes hands. Apart from stressing the relative worth of wealth, wisdom tradition pities the poor: "Wild desert donkeys are the prey of lions; so too, the poor is the quarry of the rich" (Sir 13:19). 1 Enoch 94:9 places wealth in relationship to God: "Woe unto you, O rich people! For you have put your trust in your wealth. You shall ooze out of your riches, for you do not remember the Most High" (trans. Charlesworth 1983:75). Between Jesus' parable of the rich fool in Luke 12:16-21, James 1:9-11 and the critique against the unjust in 1 Enoch 97:8-10 there is one striking parallel: death or final judgment will separate the rich from their wealth. ${ }^{5}$

Christian admonition in the name of Jesus continued wisdom instruction as can be seen from Luke 12:15: "And he said to them, 'Take care! Be on your guard against all kinds of greed; for one's life does not consist in the abundance of possessions." It is thus necessary to look in more detail to the Jesus tradition.

There is more to it than the wise summary of life experience that human life in its brevity ends, regardless of the individual's wealth and prosperity. The crucial question is what guides the action during life. A few examples should suffice. What is important to people, their treasures, give them orientation in life, affect their hearts. The instruction in $\mathrm{Q}$ (Matt 6:19-21/Luke 12:33-34; cf. Jas 5:3) not to store treasures on earth "where moth and rust consume and where thieves break in and steal" but rather in heaven, is thus motivated by a final clause, "where your treasure is, there your heart will be also." The rich man (cf. Mark 10:21-25) followed the Torah, but was not able to sell what he owned, to give the money to the poor, and to follow Jesus. The reason for this was "he had many possessions." The comment of Mark's Jesus is telling, "How hard it will be for those who have wealth to enter the kingdom of God!" Afterwards he reiterates this during a special instruction to his perplexed disciples: "Children, how hard it is to enter the kingdom of God! It is easier for a camel to go through the eye of a needle than for someone who is rich to enter the kingdom of God." (Mark 10:24-25). It is his possessions which kept the rich man from following Jesus.

What really matters, to put it according to Matthew, are the weightier matters of the law: "justice and mercy and faith" $(23: 23)$. True religion, worship, so the Epistle of James $(1: 27)$, states is measured against the stance it takes towards those who were the most vulnerable in ancient patriarchal society, orphans and widows. ${ }^{6}$ By the middle of the 2nd

All translations of Sir taken from New Jerusalem Bible (NJB). Cf. also Sir 13:3; 31:3-5.

1 En. 97:8-10: "Woe unto you who gain silver and gold by unjust means; you will then say: 'We have grown rich and accumulated goods, We have acquired everything that we have desired. So now let us do whatever we like; for we have gathered silver, we have filled our treasuries (with money) like water. And many are the laborers in our houses.' Your lies flow like water. For your wealth shall not endure but it shall take off from you quickly for you have acquired it all unjustly, and you shall be given over to a great curse" (trans. Charlesworth 1983:78).

6 The proof of faith lies in the help rendered to the poor: "If a brother or sister is naked and lacks daily food, and one of you says to them, 'Go in peace; keep warm and eat your fill,' and yet you do not supply their bodily needs, what is the good of that?" (Jas 2:15-16). 
century the Shepherd of Hermas, who almost made it into the canon, ${ }^{7}$ illustrates clearly that this tradition still bore fruit in the Christian community of Rome:

First of all: faith, fear of the Lord, love, harmony, words of righteousness, truth, and endurance. Nothing in human life is better than these. Anyone who guards them and does not refrain from exercising them is happy in his life. Listen then to what follows from these: ministering to widows, visiting orphans and those in need, redeeming the slaves of God from their calamities, being hospitable, ... (Herm. Mand. 8:910) ${ }^{8}$

The widows and the orphans were the most vulnerable in ancient society, since they could no longer count on the support of the pater familias. If there were no father or brother, father in law or brother in law to step in to support them, the Christian community had to step in.

In the traditions of Israel and early Judaism, the spread of the good news was closely associated with the end of poverty in Deutero-Isaiah (cf. Isa 61:1) and amongst the Qumran community. ${ }^{9}$ Jesus of Nazareth's ministry was placed within this trajectory, ${ }^{10}$ which resonates through the synoptic tradition (cf. Mark 7:37; Luke 4:1620). From the early years on, charity (eleos) is a guiding value. Matthew even found it necessary to give guidelines for the practice of alms giving. It should be done discreetly and not as if one is a Greek benefactor seeking honour for well-doing: "But when you give alms, do not let your left hand know what your right hand is doing" (Matt 6:3). Early Christianity did not strive to eradicate poverty, remembering that Jesus said, "you always have the poor with you, and you can show kindness to them whenever you wish" (Mark 14:7). But the stories of the rich man (Mark 10:2125) and of Zacchaeus, the rich tax collector (Luke 19:210), make clear that the rich were obliged to give of their possessions to the poor. In the case of Zacchaeus there is even a word of retribution: "Look, half of my possessions, Lord, I will give to the poor; and if I have defrauded anyone of anything, I will pay back four times as much" (Luke 19:8).

Early Christianity followed the instruction of Jesus. The way in which those who had left their trade and income in Galilee and resettled in Jerusalem, or migrants from the Diaspora were supported by the resident part of the Jerusalem congregation in the first years is well known (Acts 2:4247; 4:3237; 9:3643; 10:2, 4, 31; cf. 1QS 1:1112; 4:1323). For Paul, Jesus' personal example was also a motivation. At the meeting of the apostles in Jerusalem in A.D. 48 Paul and Barnabas promised to support the poor in Jerusalem (Gal 2:10), which Paul did through the collection for the poor in Jerusalem in the congregations he found in Galatia, Asia, Macedonia, and Achaia (Gal 2:10; 2 Cor 8:2, 7; 9:5-7, 11-13). Paul urges the congregations to follow the example of Christ: "For you know the generous

7 The Muratorian fragment recommended its reading and Origen fancied it. In the 4th century the text of Herm. (until Mand. 4:3) follows Barn. after the New Testament in Codex Sinaiticus. For more detail see the commentaries of Brox (1991) and Osiek (1999).

8 All translations of Herm. taken from Ehrman 2003.

9 Cf. 4Q521 frgs. 2, col. 2, and frg. 4, 11. 11-13: “And the Lord shall do glorious things which have not been done, just as He s[aid.] For He shall heal the critically wounded, He shall revive the dead, 'He shall send good news to the afflicted,' (Isa 61:1). He shall sati[sfy] the [poor], He shall lead the uprooted, and the hungry He shall enrich(?)" (trans. Parry and Tov 2005:159-161).

10 Q relates the question John the Baptist's disciples put to Jesus whether he is the one that was expected and Jesus' answer (Luke 7:22/Matt 11:5): "Go and tell John what you have seen and heard: the blind receive their sight, the lame walk, the lepers are cleansed, the deaf hear, the dead are raised, the poor have good news brought to them." 
act of our Lord Jesus Christ, that though he was rich, yet for your sakes he became poor, so that by his poverty you might become rich" (2 Cor 8:9).

One may be tempted to see a tendency against wealth in some of the blessings from $Q$ and in the woe sayings added in Luke, ${ }^{11}$ but one must realize that this is wisdom tradition with an apocalyptic taint. In the light of the finiteness of life and the final consummation, the worth of wealth is restricted. ${ }^{12}$ It is not wealth that is evil per se, riches are a gift from God, part of his creation. The question is how humans relate to their possessions. There is a right and a wrong way. One can use Mammon or be abused by him. Material goods should be used in the right manner. The parables of the unjust steward and of the rich man and Lazarus in Luke 16 clearly illustrate that wealth should be used in the light of the future. Rescinding his own commission, the unjust steward gives discount on the obligations the tenants had towards his lord, hoping that when he is in trouble, they will look after him in future. Forward-looking, he acts now. According to the next parable in Luke 16, the rich man focuses on his wealth and ignores Lazarus. He does not make friends on the basis of what is called the unjust Mammon (16:9), he does not follow the Law and the Prophets (16:31), and in the end he perishes (cf. Breytenbach 2006:143-144). Hermas develops the theme of what the duty of the rich Christians is: It is all about sharing. At the end of his similitude, the vine (stands for the poor) suspended/trained upon the elm (stands for the rich). Hermas reformulates the principle in the form of a blessing: "Happy are they who have possessions and understand that their riches come from the Lord; for the one who understands this will also be able to perform a good ministry." (Herm. Sim. 2:10). If the rich cannot separate themselves from their wealth, they become useless for the Lord (cf. Brox 1991:518-519).

Rather than assuming a principal tendency against wealth, there are warnings against the wealthy and the needy. The orientation of the wealthy should be correct. In the first vision Hermas says that for "those who are invested in this age who rejoice in their wealth and do not cling to the good things yet to come" it is difficult to fit the rich into the building of the congregation (Herm. Vis. 1:1). They are the stones that are not easy to build with, they are "white and round," but do not fit into the building of the tower. They have faith indeed, but they have also the riches of this world. When, therefore, tribulation comes on account of their riches and business they deny the Lord (Herm. Vis. 3:6). The rich are thus not disqualified because they are rich, but because their hearts are where their treasures are, their actions are money-orientated and not towards the help for the poor. The Shepherd admonishes the rich to share with the poor: "Do what is good, and take what you have earned through the toils God has given you and give simply to those in need, not wavering about to whom you should give something and to whom not. Give to everyone. For God wishes everyone to be given something from his own gifts" (Herm. Mand. 2:4).

It is no excuse to say that those who ask and receive do not deserve the help. The Shepherd shifts the responsibility to the receiver and warns the needy, too: "And so, those who receive something will render an account to God, about why they received something and to what end. For those who received because of hardship will not face condemnation;

\footnotetext{
11 Luke 6:20-21/Matt 5:3, 6: "Then he looked up at his disciples and said: 'Blessed are you who are poor, for yours is the kingdom of God. Blessed are you who are hungry now, for you will be filled." Luke 6:24-25: "But woe to you who are rich, for you have received your consolation. Woe to you who are full now, for you will be hungry."

12 Cf. also Luke 14:7ff., 13-14, 21; Jas 1:9-11.
} 
but those who received out of hypocrisy will pay a penalty. And so the one who gives is innocent" (Herm. Mand. 2:5-6).

Could one say that early Christianity had a preference for the poor? Luke's Jesus starts his sermon in Nazareth with a quotation from Isaiah 61:1: "The Spirit of the Lord is upon me, because he has anointed me to bring good news to the poor. He has sent me to proclaim release to the captives and recovery of sight to the blind, to let the oppressed go free, to proclaim the year of the Lord's favor" (Luke 4:18-19). Rather than speaking of the preference for the poor only, one should also remember that the help for the poor could be to the advantage of the rich, as the following lines from Hermas, hinting on what today will run under obesity and malnutrition, illustrate:

And so, now, listen to me: be at peace with one another, take care of one another, help one another; and do not take an overabundance of God's creations for yourselves, but share with those in need. For those who enjoy many kinds of food make their flesh weak and harm it; but the flesh of those without enough food is harmed by lack of proper nourishment, and their body wastes away. This disparity is harmful to you who have but do not share with those in need. Consider the judgment that is coming. You who have an abundance should therefore seek out the hungry, before the tower is completed. For after the tower is completed you will long to do good but will have no opportunity (Herm. Vis. 3:9)

The reason why people must share is grounded in the confession to the one God, the Creator. Everything belongs to him. As Hermas puts it: "Give to everyone. For God wishes everyone to be given something from his own gifts" (Herm. Mand. 2:4). God's gifts to the rich are given with the purpose that the affluent can help the poor and the afflicted. The wealthy should understand that these are gifts from God to be used to help the poor and afflicted. "For this is why the Master made you rich, that you may carry out these ministries for him" (Herm. Sim. 1:9). ${ }^{13}$

We saw that the "James test" for Christian faith is the care for the needy. He is not alone with this. For Matthew what really matters in the law is justice and compassion. In the tradition of the Law and the Prophets, "ministering to widows, visiting orphans and those in need, redeeming the slaves of God from their calamities, being hospitable" are those things that are important to Hermas (Herm. Mand. 8:10). This is specifically the duty of the bishops. "Through their ministry, the bishops always provided constant shelter $(\sigma \kappa \varepsilon \pi \zeta \omega)$ for those in need and for the widows, and they always conducted themselves in a holy way" (Herm. Sim. 9:27). Such requirements of the bishops are developed further in the third century as we can see from the Syrian Didascalia: "Let his hand be open to give; and let him love the orphans with the widows, and be a lover of the poor and of strangers." (Didascalia 4.2.4). ${ }^{15}$ Drawing on Paul (1 Cor 9:1-18), who drew on Jesus, this Syrian Order of the Church acknowledges that "the bishops ought to be nourished from the revenues of the Church, but not to devour them; for it is written: Thou shalt not muzzle the ox that treadeth out (the corn). As then the ox which works unmuzzled in the threshing floor eats, indeed, but does not consume the whole" (Didascalia 8).

By putting the care for the needy in the hands of the top official, the early Church underlined the importance of the care for the poor and the need to protect such measures

\footnotetext{
13 On the relation between poor and rich in Hermas, cf. Osiek 1983 and Osiek 1999.

14 Cf. Rowland 1999 and Dibelius 1923, 527.

15 All trans. of Didascalia taken from Connolly 1969.
} 
from corruption. Mammon should be used, not let loose. The bishop himself is in charge of the measures against Mammon to use him for the good.

How did Christianity succeed disseminating this value into modern cultures?

\section{Modern Medicine Men}

In the last section I turn to modern medicine men. With that I do not mean traditional healers, but the modern doctors. I briefly argue that medical care, when detached from the motive to take compassionate care and administered with the intention to serve Mammon, fails to respect the dignity of humans. ${ }^{16}$ But why not rather have a look at Mammon and sport? I agree that after the betting in cricket and doping in cycling and amidst the unfolding drama of fraudulent soccer games, it is clear to see that the way in which money is involved in sport does not serve the long term interests of the athletes or sport itself. Mammon is served and sport is despised.

For historical reasons this is not a good example, for Jesus certainly did not compete in a stadium and Paul was merely an Olympian of the rhetorically arguing letter. The outcry to return to amateur sport illustrated the longing of a cultural value: the principle of non profit driven competition. When the laurels were traded for money, sport became sick, and got Mammon's disease.

Since Jesus was a healer and the gospel the message of the healing of the sick, the blind, the deaf, I stay with the healers. Christianity has a long tradition of medical care, building hospitals, nursing the sick. The poor and the sick belong together, because they are those in need.

One of the major questions of our times is the affordability of medical care. Here Christianity must cherish their value that money has to be used to do good, that it has to take care for those in distress. The rich man has to look after Lazarus at his gates, he is not allowed to make more money out of Lazarus by selling his kidneys. The bishop should look after the widow and the orphans, the widow and the orphans being a symbol for those who had no chance in ancient society. He should put them under the shade of his care.

It is time to challenge modern medicine men with the age-old Christian value, that justice, compassion, and mercy are weightier matters of the law, that clean and undefiled

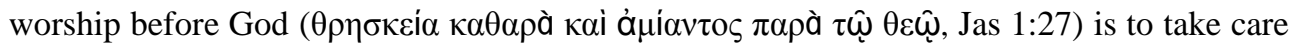
of those in affliction. When one reads of US programmes to pay hospitals for performance, that means the income of the hospital is directly connected to the number of successful treatments; when one remembers the 1977 Harvard Report, which concluded that surgeons perform too much surgery in the United States, including hysterectomies, Caesarean sections and coronary artery bypass surgeries; when one thinks about the recent hysterectomy scam in India, then it becomes clear that the choice to serve Mammon defies the dignity of the human body and changes the obligation to take care of those in need because they are in need, into a decision to exploit those who can afford it. If medicine

This topic deserves to be discussed in full with all stakeholders, perhaps on a separate conference. In the context of the original conference (cf. note 1) I could merely indicate the impulse from early

Christian tradition. 
serve Mammon it despises the image of God. Here we need a global debate to which Christianity can make an important contribution.

\section{Conclusions}

I aim to revitalize traditional Christian values to prevent them from getting lost. For the Judaeo-Christian tradition, the confession to one living God is the cornerstone of the intracultural encounter. For Christianity the relative worth of wealth is an essential principle. Mammon is to be used in view of the future good of humanity. The task of interpreting tradition is a common theological one. In taking care of the poor and the weak, in taking responsibility for them, there is a huge demand on the wealthy and the strong. Bearing in mind that in the beginnings of Christianity the poor and the weak were entrusted to the bishop, there is a huge responsibility on church leadership.

Reinterpreting eschatology, we have to ask what serves the long term dignity of humanity. If we let Mammon loose and do not integrate him into that which sustains and dignifies human life, we must remember the judgement will come for the rich and the wealthy, maybe not always during their lifespan, but sometimes in the lives of the third and the fourth generations. Life on earth will become intolerable. The choice for an unbridled Mammon is the choice against the future of humankind. "No servant can serve two masters: for either he will hate the one, and love the other; or else he will hold to the one, and despise the other. Ye cannot serve God and mammon" (Matt 6:24).

\section{BIBLIOGRAPHY}

Breytenbach, Cilliers 1996. Paulus und Barnabas in Galatien. Arbeiten zur Geschichte des antiken Judentums und des Christentums 38. Leiden: Brill.

2006. "Was die Menschen für großartig halten, das ist in den Augen Gottes ein Greuel" (Lk 16,15c). Geld angesichts des Eschatons. Jahrbuch für Biblische Theologie 21:131-144.

Breytenbach, Cilliers, and Christiane Zimmermann. Forthcoming. Early Christianity in Lycaonia. Ancient Judaism and Early Christianity. Leiden: Brill.

Brox, Norbert 1991. Der Hirt des Hermas. Kommentar zu den Apostolischen Vätern 7. Göttingen: Vandenhoeck.

Charlesworth, James H 1983. The Old Testament pseudepigrapha. Vol. 1, Apocalyptic literature and testaments. London: Darton, Longman \& Todd.

Connolly, R Hugh 1969. Didascalia Apostolorum: The Syriac version translated and accompanied by the Verona Latin fragments. Oxford: Clarendon Press.

Destephen, Sylvain 2008. Prosopographie du Diocèse d'Asie (325-641). Vol. 3 of Prosopographie chrétienne du Bas-Empire. Paris: Association des amis du centre d'histoire et civilisation de Byzance.

Dibelius, Martin 1923. Der Hirt des Hermas. Handbuch zum Neuen Testament 20. Tübingen: Mohr. 
Early Christian Values in Cultural Encounter, Zeus, Mammon and Modern Medicine Men 11

Ehrman, Bart D 2003. The apostolic fathers. Vol. 2, Epistle of Barnabas, Papias and Quadratus, Epistle to Diognetus, the Shepherd of Hermas. Loeb Classical Library 25. Cambridge: Harvard University Press.

Hütteroth, Wolf-Dieter, and Volker Höhfeld 2002. Türkei. Wissenschaftliche Länderkunde. Darmstadt: Wissenschaftliche Buchgesellschaft.

Osiek, Carolyn 1983. Rich and poor in the Shepherd of Hermas: An exeget.-social investigation. Washington, DC: Catholic Biblical Association of America. 1999. Shepherd of Hermas: A commentary. Hermeneia. Minneapolis: Fortress Press.

Parry, Donald W, and Emanuel Tov, (eds.) 2004. The Dead Sea Scrolls reader. Vol. 1, Texts concerned with religious law. Leiden: Brill.

2005. The Dead Sea Scrolls reader. Vol. 6, Additional genres and unclassified texts. Leiden: Brill.

Rowland, C (ed.) 1999. The Cambridge companion to liberation theology. Cambridge: University Press.

Robinson, James M et al., (eds.) 2001. The sayings gospel Q in Greek and English with parallels from the Gospels of Mark and Thomas. Contributions to Biblical Exegesis and Theology 30. Leuven: Peeters. 